\title{
THE IMPORTANCE OF PROLONGED INCUBATION FOR THE SYNTHESIS OF DIMETHYLNITROSAMINE BY ENTEROBACTERIA
}

\author{
P. J. Coloe and Nancy J. Hayward \\ Department of Microbiology, Monash University Medical School, \\ Prahran 3181, Australia
}

THE experimental demonstration that nitrosamines are carcinogenic, mutagenic and teratogenic (Magee, 1969) has raised the question of their potential danger to man, and prompted studies of the circumstances that might expose him to them. Nitrosamines have been found in a limited number of foods for human consumption (International Agency for Research on Cancer, 1972), and have been shown to be produced by bacteria that occur in food (CollinsThompson et al., 1972; Fong and Chan, 1973). They may be produced in vivo from nitrites and either secondary amines (Sander, Schweinsberg and Menz, 1968; Sen, Smith and Schwinghamer, 1969; Lijinsky and Epstein, 1970; Mirvish, 1970) or tertiary amines (Lijinsky, 1974) at the $p \mathrm{H}$ of the stomach.

The possibility of bacterial production of nitrosamines from secondary amines in the presence of nitrate or nitrite in vivo at sites with a $p \mathrm{H}$ closer to neutrality has been raised. Production in vitro has been shown with single strains of four nitrate-reducing members of the enterobacteriaceae, Escherichia coli, E. dispar, Proteus vulgaris and Serratia marcescens, from secondary amines at neutral $p \mathbf{H}$ (Sander, 1968). Hawksworth and Hill (1971) found that $27 \%$ of 37 strains of $E$. coli and a proportion of strains of other faecal aerobes and anaerobes were able to produce nitrosamines from nitrate and diphenylamine at a $p \mathrm{H}$ above 6.5. These authors (Hill and Hawksworth, 1972) consider that the most likely site of in-vivo bacterial production of nitrosamines is the urinary tract, because the substrates, nitrate and secondary amines (principally dimethylamine, DMA), are found in urine-and bacteria with both nitrate-reducing and nitrosamine-forming enzymes may be present during infection. The in-vitro production of dimethylnitrosamine (DMN) by three strains each of $P$. mirabilis, $P$. morganii and $P$. rettgeri from urine, and the detection of $\mathrm{DMN}$ in the urine of two patients with urinary-tract infections caused by $\boldsymbol{P}$. mirabilis, supports this suggestion (Brooks et al., 1972; Thacker and Brooks, 1974). Nitrosamines produced by bacteria during urinary-tract infections may cause cancer in distant anatomical sites (Hill, Hawksworth and Tattersall, 1973; Hawksworth and Hill, 1974).

The present survey was undertaken to define which of the bacteria commonly associated with urinary-tract infection are able to produce DMN. The survey of faecal bacteria by Hawksworth and Hill (1971) appears to show that production of diphenylnitrosamine is not a constant feature of all strains of any species. Similarly, we have found wide variation among strains when we tested bacteria that may cause urinary-tract infections for their ability to produce

Received 28 Oct. 1975; accepted 2 Dec. 1975.

J. MED. MICROBIOL.- VOL. 9 (1976) 
DMN-but only when we used the accepted test incubation period of $24 \mathrm{~h}$. When we extended the test incubation-period to $70 \mathrm{~h}$, almost all of 136 strains of nitratase-positive enterobacteria produced DMN from DMA and nitrate.

\section{Materials ANI) METhods}

Organisms. A total of 153 strains included 52 E. coli, 23 Klebsiella aerogenes, two $K$. ozaenae, $36 P$. mirabilis, $17 P$. vulgaris, $11 P$. rettgeri and $12 P$. morganii. One hundred of these strains were obtained from clinical material submitted to our laboratory and included isolates from specimens of urine (76), faeces (15), pus (three), sputum (one) and blood (one) or from nasal swabs (two), an eye swab and a cervical swab. A further 53 strains were obtained from culture collections at Alfred Hospital, Melbourne (22), National Collection of Type Cultures, London (16), National Institute of Health, Wellington, New Zealand (eight), Monash University Culture Collection (three), Queensland University Culture Collection (three) and Institute of Medical and Veterinary Science, Adelaide (one). Strains used for particular experiments in addition to the general survey were the following: $P$. mirabilis no. B2; $P$. vulgaris no. B14 and $E$. coli no. B78, isolated from urine; $P$. vulgaris no. A15, from a nasal swab; $P$. mirabilis no. B15, from faeces; and $E$. coli no. A2, from pus.

All organisms were identified, and nitrate reduction was determined, by the methods of Cowan and Steel (1965).

Chemicals. DMA in ethanol $(33 \% \mathrm{w} / \mathrm{w}), \mathrm{DMN}$, dichloromethane, acetone, sodium nitrite and potassium nitrate were purchased from E. Merck, Darmstadt, Germany. Whenever possible, biochemical-grade chemicals from British Drug Houses were used for the preparation of defined media.

Media. Defined medium was prepared from four solutions which were sterilised and stored separately and mixed when required: 1 litre of the medium contained $780 \mathrm{ml}$ of the basal salts solution and $100 \mathrm{ml}$ of the complex amino-acid solution of Proom and Knight (1955), the former sterilised by autoclaving at $121^{\circ} \mathrm{C}$ for $15 \mathrm{~min}$. and the latter by filtration through a Gallenkamp Sinta-glass filter of porosity $5 ; 20 \mathrm{ml}$ of a filter-sterilised vitamin solution containing biotin $1.0 \mu \mathrm{g}$, folic acid $2.0 \mu \mathrm{g}$, riboflavin $0.1 \mathrm{mg}$, thiamine hydrochloride $0.5 \mathrm{mg}$, nicotinic acid $0.5 \mathrm{mg}$, pyridoxal hydrochloride $0.5 \mathrm{mg}$ and calcium pantothenate $0.5 \mathrm{mg}$; and $100 \mathrm{ml}$ of a $30 \%(\mathrm{w} / \mathrm{v})$ glucose solution sterilised by autoclaving at $110^{\circ} \mathrm{C}$ for $20 \mathrm{~min}$. The defined medium, enriched with $0.09 \mathrm{M}$ or $0.022 \mathrm{M}$ DMA or $0.1 \mathrm{M}$ or $0.025 \mathrm{M}$ $\mathrm{KNO}_{3}$ or $0.1 \mathrm{M}$ or $0.025 \mathrm{M} \mathrm{NaNO}{ }_{2}$ or any combination of these, was adjusted to $p \mathrm{H} 7.4$ and sterilised by filtration through sintered glass.

MacConkey Agar (Oxoid) was prepared as directed by the manufacturers. Blood agar contained Nutrient Broth no. 2 (Oxoid) $2.5 \%(\mathrm{w} / \mathrm{v})$, Powdered Yeast Extract (Oxoid) $0.3 \%(\mathrm{w} / \mathrm{v}$ ), Agar no. 3 (Oxoid) $1.2 \%(\mathrm{w} / \mathrm{v})$, and defibrinated horse blood (Bio-Science Laboratories) $3 \%(\mathrm{v} / \mathrm{v})$. The agar concentration was increased to $3.6 \%$ for firm blood agar to prevent the swarming of Proteus spp. Peptone water was prepared from Bacteriological Peptone (Oxoid) as described by Cowan and Steel (1965).

Culture conditions. Volumes of defined medium $(20 \mathrm{ml})$ were dispensed aseptically into 30-ml sterile screw-capped "Universal" bottles, seeded with c. $10^{6}$ organisms per $\mathrm{ml}$ and incubated unshaken at $37^{\circ} \mathrm{C}$. MacConkey's agar and blood agar for viable counts were incubated at $37^{\circ} \mathrm{C}$ for only $12 \mathrm{~h}$ to restrict colony size to $0 \cdot 5-1 \mathrm{~mm}$ and so increase the accuracy of counting.

Measurement of growth. Optical densities (OD) of suspensions were measured as extinction values at $500 \mathrm{~nm}\left(\mathrm{E}_{500}\right)$ in a Bausch and Lomb Spectronic 20 colorimeter. Viable counts were performed by the method of Miles, Misra and Irwin (1938). Dilutions were prepared in $1 \%$ peptone water and one drop of each dilution was placed on each of eight MacConkey's agar plates and one blood-agar plate. The cultures before dilution were streaked on blood agar to check their purity.

Extraction of $D M N$. Cultures and standard solutions were adjusted to $p \mathrm{H} 12-13$ by 
adding $1 \mathrm{ml}$ of $10 \mathrm{M} \mathrm{NaOH}$ and extracted twice with $10 \mathrm{ml}$ of dichloromethane. The dichloromethane extracts were pooled, saturated with anhydrous $\mathrm{K}_{2} \mathrm{CO}_{3}$ to remove any water, filtered through Whatman no. 1 filter paper to remove the $\mathrm{K}_{2} \mathrm{CO}_{3}$, transferred to a $50-\mathrm{ml}$ round-bottomed flask, evaporated under column reflux at $60^{\circ} \mathrm{C}$ to remove the dichloromethane, redissolved in $0.5 \mathrm{ml}$ of acetone and evaporated to remove the acetone and any residual dichloromethane. The residue, redissolved in $0.1 \mathrm{ml}$ of acetone, was used for gaschromatographic analysis. A standard $0.0009 \mathrm{M}$ solution of $\mathrm{DMN}$ in defined medium was extracted as a control with each batch of test samples.

Detection of $D M N$. DMN was detected by gas-liquid chromatography by means of a Perkin-Elmer model 881 gas chromatograph equipped with a flame ionisation detector and a glass column $[1.83 \mathrm{~m}(6 \mathrm{ft}) \times 6.35 \mathrm{~mm}(0.25 \mathrm{in}$.) outside diameter] packed with Chromosorb 103 (Tracor, Analytical Instruments Division, Austin, Texas, USA). The carrier gas was nitrogen and the flow rate $20 \mathrm{ml}$ per min.; the column-oven temperature was $180^{\circ} \mathrm{C}$, the detector temperature $210^{\circ} \mathrm{C}$, and the injector temperature $200^{\circ} \mathrm{C}$. DMN from bacterial cultures was identified initially by comparison of the retention times of unknown peaks with authentic DMN and by mass-spectrometry. In subsequent experiments, DMN was determined both qualitatively and quantitatively by comparison of the retention times and peak areas of extracts of DMN from bacterial cultures with extracts of the standard $0.0009 \mathrm{M}$ solution of DMN. The limit of detection of DMN was $0.09 \mu$. moles per $20 \mathrm{ml}(4.5 \mu \mathrm{M})$.

Reproducibility of results. Twenty-eight $0.0009 \mathrm{M}$ DMN standards analysed during the survey ranged in peak area from 75.4 to $109.2 \mathrm{~cm}^{2}$ with a mean of $92.28 \mathrm{~cm}^{2}$ and a standard deviation of $8.57 \mathrm{~cm}^{2}$. The maximum variation from the mean was $18 \%$. The small final volume of sample $(0.1 \mathrm{ml})$ needed to provide a detectable concentration of DMN without the use of very large volumes of defined medium tended to add to the experimental error inherent in the number of steps required for extraction.

\section{RESULTS}

\section{Bacterial production of dimethylnitrosamine in cultures at $24 \mathrm{~h}$}

The results from the 153 cultures grown for $24 \mathrm{~h}$ in defined medium supplemented with $0.09 \mathrm{M}$ DMA and $0 \cdot 1 \mathrm{M} \mathrm{KNO}_{3}$ are shown in table I. Some strains of all species produced detectable DMN; there was wide variation in amounts

TABLE I

Dimethylnitrosamine $(D M N)$ production in 24-h cultures in defined medium supplemented with $0.09_{M}$ dimethylamine $(D M A)$ and $0.1_{M}$ potassium nitrate

\begin{tabular}{|c|c|c|c|c|c|}
\hline Species & $\begin{array}{l}\text { Number } \\
\text { of strains } \\
\text { tested }\end{array}$ & $\begin{array}{c}\text { Number } \\
\text { producing* } \\
\text { detectable } \\
\text { DMN }\end{array}$ & $\begin{array}{l}\text { Number } \\
\text { producing } \\
>0.09 \mathrm{mM} \\
\mathrm{DMN}\end{array}$ & $\begin{array}{l}\text { Maximum } \\
\text { concentration } \\
\text { of DMN } \\
\text { produced } \\
\text { (mM) }\end{array}$ & $\begin{array}{c}\text { Range of } E_{500} \text { readings } \\
\text { (turbidity of test } \\
\text { cultures) }\end{array}$ \\
\hline $\begin{array}{l}\text { Escherichia coli } \\
\text { Klebsiella aerogenes } \\
\text { K. ozaenae } \\
\text { Proteus mirabilis } \\
\text { P. vulgaris } \\
P . \text { rettgeri } \\
P . \text { morganii } \\
\quad \text { Any }\end{array}$ & $\begin{array}{r}52 \\
23 \\
2 \\
36 \\
17 \\
11 \\
12 \\
153\end{array}$ & $\begin{array}{r}38 \\
23 \\
2 \\
26 \\
8 \\
7 \\
4 \\
408\end{array}$ & $\begin{array}{r}14 \\
18 \\
0 \\
18 \\
8 \\
5 \\
1 \\
64\end{array}$ & $\begin{array}{l}0 \cdot 36 \\
0 \cdot 32 \\
0 \cdot 08 \\
0 \cdot 35 \\
0 \cdot 30 \\
0 \cdot 34 \\
0 \cdot 20 \\
\ldots\end{array}$ & $\begin{array}{c}0.34-3 \cdot 0 \\
0.84-1.84 \\
1 \cdot 46-1.65 \\
0 \cdot 19-0.98 \\
0.035-0.185 \\
0 \cdot 18-0.74 \\
0 \cdot 24-0.96 \\
\ldots\end{array}$ \\
\hline
\end{tabular}

* The limit of detection of DMN was $0.09 \mu$. moles per $20 \mathrm{ml}$, equivalent to $4.5 \mu \mathrm{M} \mathrm{DMN}$. 
TABLE II

Dimethylnitrosamine (DMN) production in 24-h cultures of the same strains tested on three occasions

\begin{tabular}{c|ccc}
\hline Species & \multicolumn{3}{|c}{ Concentration of DMN produced (mM) } \\
\hline E. coli & 0.35 & 0.36 & 0.26 \\
P. mirabilis & 0.16 & 0.08 & 0.12 \\
P. mirabilis & $<0.0045$ & $<0.0045$ & $<0.0045$ \\
P. mirabilis & 0.18 & 0.16 & 0.13 \\
\hline
\end{tabular}

of DMN produced by individual strains-ranging from $0.009 \mathrm{mM}$ to $0.36 \mathrm{mM}-$ and, except possibly for $K$. aerogenes, all species showed a similar variation. Control cultures of five strains of $E$. coli, three of $K$. aerogenes, one of $K$. ozaenae, six of $P$. mirabilis, three of $P$. vulgaris, two of $P$. rettgeri and two of $P$. morganii, in medium either without DMA or without $\mathrm{KNO}_{3}$, did not form any detectable DMN. There was a wide variation in final turbidity of the test cultures but DMN formation was unrelated to the degree of growth. The final $p \mathrm{H}$ of all test and control cultures ranged between 6.0 and $7 \cdot 4$ and this too was unrelated to the amount of DMN produced.

One strain of $E$. coli and three of $P$. mirabilis were tested more than once and found to be consistent in the amount of DMN produced after $24 \mathrm{~h}$ (table II).

\section{Time course of production of DMN}

One strain each of $P$. mirabilis, $E$. coli and $K$. aerogenes, selected because they produced high yields of DMN, were used to follow DMN production and growth for $48 \mathrm{~h}$ (fig. 1). In all three cultures DMN production lagged about $12 \mathrm{~h}$ behind growth, starting when the cells were reaching the stationary phase and continuing to increase although the organisms were dying. This was confirmed by more prolonged incubation of three strains of $E$. coli and two strains each of $K$. aerogenes and $P$. mirabilis, chosen because they were typical of strains producing large, medium and small amounts of DMN at $24 \mathrm{~h}$ and grown in defined medium enriched with $\mathrm{DMN}$ and $\mathrm{KNO}_{3}$. Samples were taken at intervals up to $100 \mathrm{~h}$; the amounts of DMN produced and the viable counts were determined. Fig. 2 shows the results for $E$. coli strain B78 which produced a large amount and $E$. coli strain A2 which produced a small amount of DMN at $24 \mathrm{~h}$. These results are typical of those obtained with the other cultures tested. DMN production lagged well behind growth, starting when the cells reached the stationary phase and continuing to increase until about $70 \mathrm{~h}$. At least $75 \%$ and on average $85 \%$ of the DMN was produced in the period from $20-60 \mathrm{~h}$. At $18 \mathrm{~h}$, strain $\mathrm{B} 78$ produced almost three times as much DMN as strain A2, but later in the experiment the amounts of DMN were higher for strain A2. At $80 \mathrm{~h}$ all strains had produced between $1.0 \mathrm{~mm}$ and $1.2 \mathrm{~mm}$ DMN. The amount of DMN present in the cultures did not decrease during the course of the experiment. 

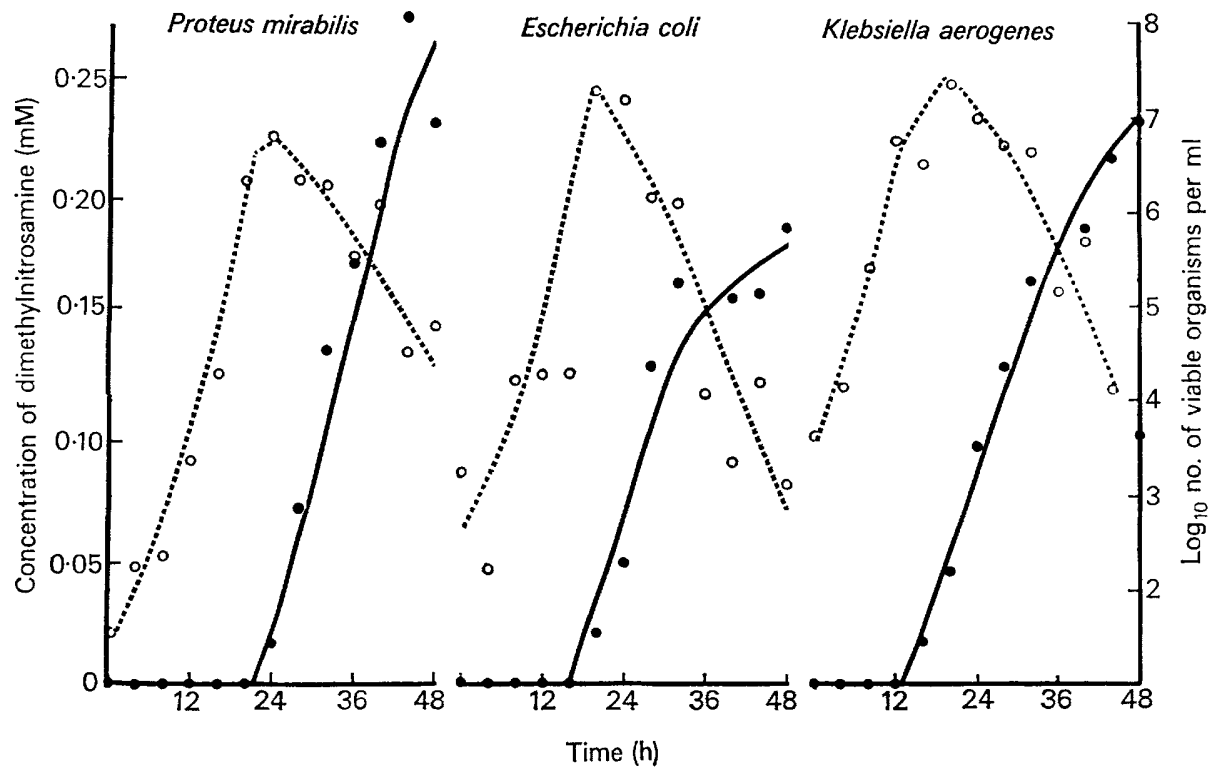

FiG. 1.-Growth and dimethylnitrosamine production in defined medium supplemented with $0.09 \mathrm{M}$ dimethylamine and $0.1 \mathrm{~m}$ potassium nitrate by species of enterobacteria: $\mathrm{O} . . .-\mathrm{O}=$ viable count; $=$ concentration of dimethylnitrosamine.

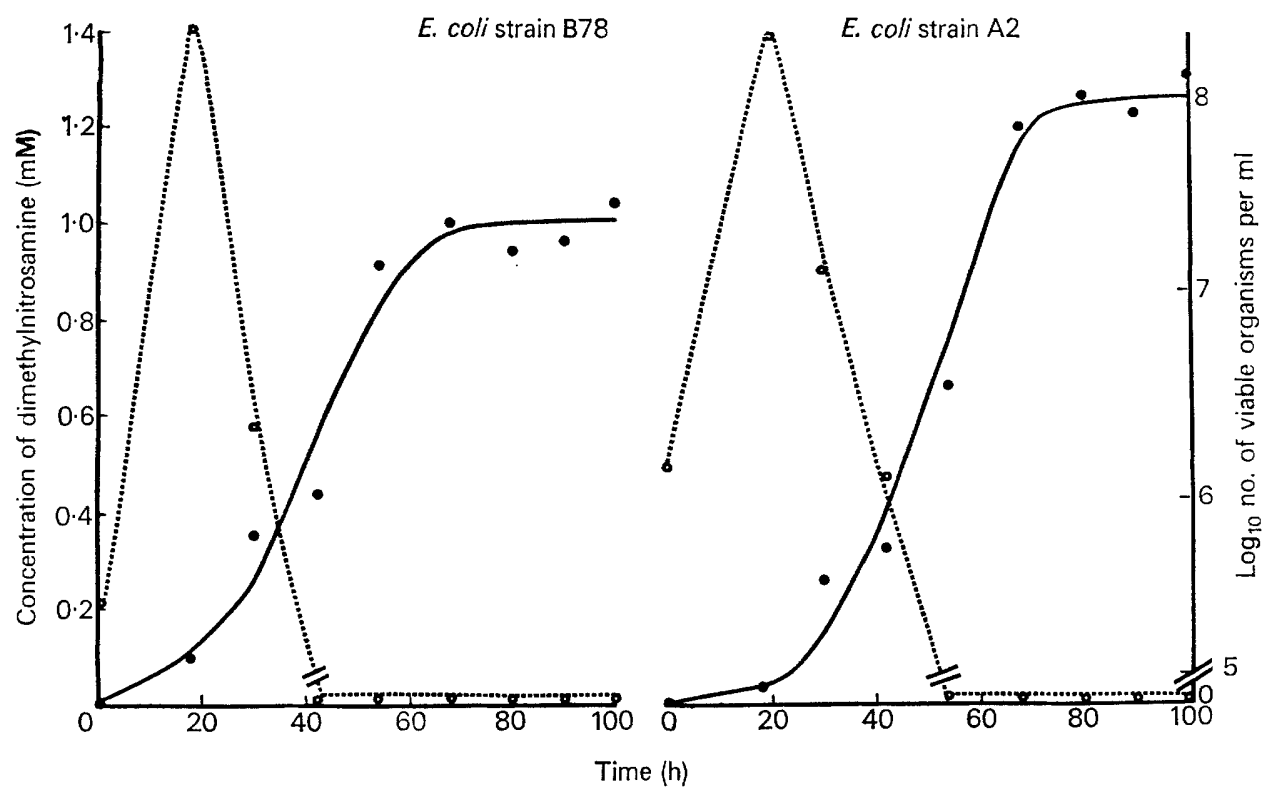

FIG. 2.-Growth and dimethylnitrosamine production in defined medium supplemented with $0.09 \mathrm{M}$ dimethylamine and $0 \cdot 1 \mathrm{M}$ potassium nitrate by strains of Escherichia coli that had given high (no. B78) and low (no. A2) yields when tested at $24 \mathrm{~h}$ : $\mathrm{O}---\mathrm{O}=$ viable count; concentration of dimethylnitrosamine. 


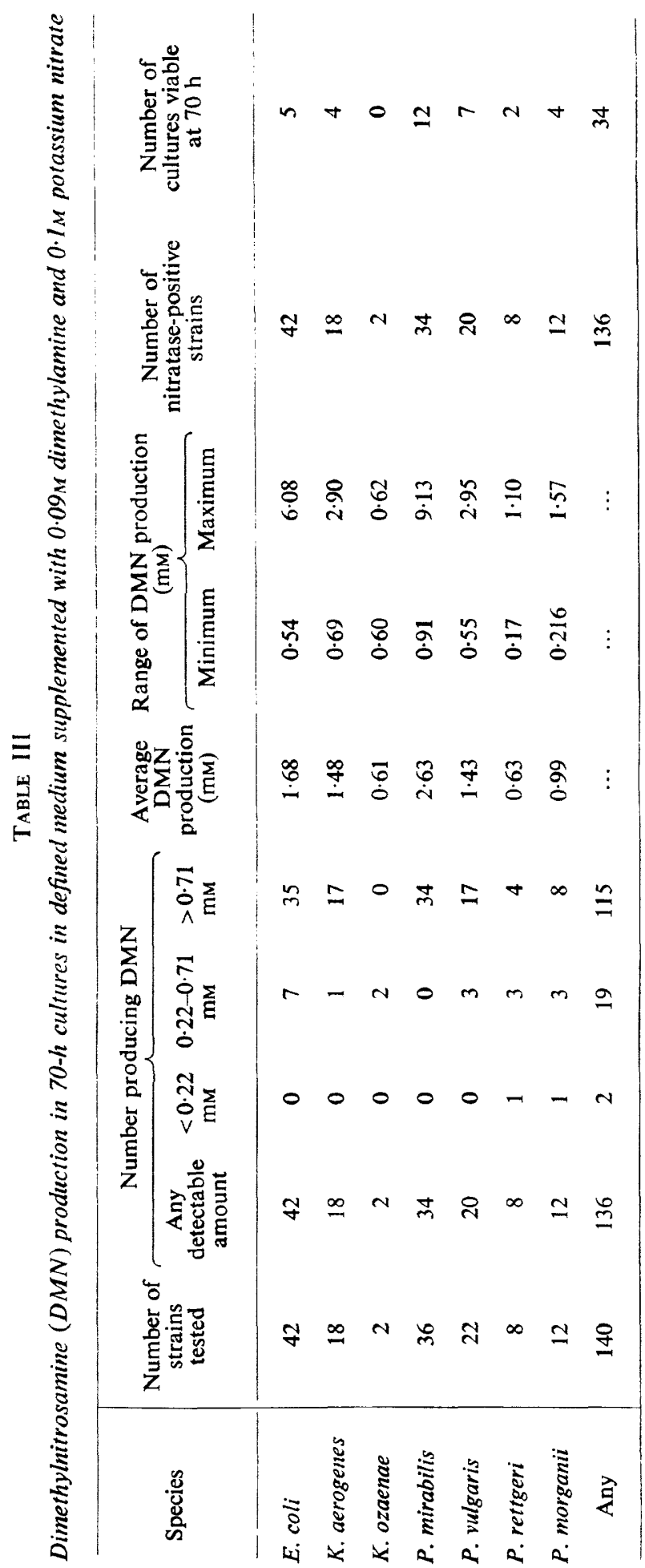


These results appear to show that the wide variation in amounts of DMN from cultures at $24 \mathrm{~h}$ (table I) may have been due to differences in rate of production of this substance rather than differences in ability to produce it.

\section{$D M N$ production in cultures at $70 \mathrm{~h}$}

The results obtained with 140 cultures, including all 45 strains that failed to produce DMN in $24 \mathrm{~h}$ (table I), grown for $70 \mathrm{~h}$ in defined medium enriched with $0.09 \mathrm{M}$ DMA and $0 \cdot 1 \mathrm{M} \mathrm{KNO} \mathrm{KN}_{3}$ are shown in table III. The yields of DMN were considerably larger than those at $24 \mathrm{~h}$. All strains tested produced detectable DMN except two $P$. mirabilis and two $P$. vulgaris strains; these four strains did not reduce nitrate to nitrite, whereas all the strains that produced DMN in $70 \mathrm{~h}$ reduced nitrate to nitrite. There was a wide variation in final turbidity, but DMN formation was unrelated to degree of growth. The final $p \mathrm{H}$ of all test and control cultures ranged only between 6.5 and 7.0 and also was unrelated to the amount of DMN produced. Control cultures of seven strains of $E$. coli, four of $K$. aerogenes, one of $K$. ozaenae, five of $P$. mirabilis and two each of $P$. vulgaris, $P$. rettgeri and $P$. morganii, in medium either without DMA or without $\mathrm{KNO}_{3}$ did not form any detectable DMN. It is of interest that the four species producing the largest yields of DMN, E. coli, K. aerogenes, $P$. mirabilis and $P$. vulgaris, are also the enterobacteria most commonly found in urinary-tract infections.

The apparently constant capacity of nitratase-positive strains to produce DMN requires qualification, because DMN can be produced non-enzymically from DMA and nitrite, albeit reportedly in very small amount at $p \mathrm{H} 6$ and not at all at $p \mathrm{H} 7$ (Mirvish, 1970). However, Mirvish incubated the reagents for only $3 \mathrm{~h}$ at $25^{\circ} \mathrm{C}$ and our cultures were held for $70 \mathrm{~h}$ at $37^{\circ} \mathrm{C}$. Valid controls to test for non-enzymic DMN formation were difficult to devise for two reasons. Firstly, the production of DMN involves two sequential reactions, the reduction of nitrate to nitrite and the subsequent formation of DMN from DMA and nitrite. Only the second reaction can occur non-enzymically in cultures. In controls containing DMA and nitrite, the second reaction started at the moment the reagents were mixed: in the cultures, non-enzymic DMN production could not start until nitrite had been formed. Simple comparison of amounts of DMN in such controls and in cultures in a given time, $24 \mathrm{~h}$ or $70 \mathrm{~h}$, could give a clear-cut answer only when the amounts of DMN in cultures were greater than in controls. This answer inevitably underestimated the enzymic capacity of some cultures that produced less DMN than the controls. Secondly, it was difficult to provide controls for the effect of $p \mathrm{H}$ because this started at $p \mathrm{H} \mathrm{7.4}$ and fell to between $6 \cdot 5$ and $7 \cdot 0$.

Two sets of controls were chosen, both consisting of uninoculated medium supplemented with $0.09 \mathrm{M}$ DMA and $0.1 \mathrm{M} \mathrm{NaNO}$, providing the maximum nitrite concentration - as if all the nitrate had been reduced immediately the tests cultures were seeded; both sets were incubated for the full $70 \mathrm{~h}$ at $37^{\circ} \mathrm{C}$, one set at $p \mathrm{H} \mathrm{7.4}$ and the other at $p \mathrm{H} \mathrm{6.5}$. No DMN was detected in either set at $24 \mathrm{~h}$. Some DMN was formed in each at $70 \mathrm{~h}, 0.71 \mathrm{~mm}$ at $p \mathrm{H} 6.5$ and 
$0.22 \mathrm{~mm}$ at $p \mathrm{H} \mathrm{7.4}$. Whilst it is confidently assumed that all 115 cultures that produced more than $0.71 \mathrm{mM}$ DMN (table III) did so enzymically, it is probable that some of the 19 that produced between $0.22 \mathrm{~mm}$ and $0.71 \mathrm{~mm}$ also possessed nitrosamine-forming enzymes. This is borne out by the fact that no nonenzymic control yielded any DMN at $24 \mathrm{~h}$ and yet six of the 19 cultures produced DMN at $24 \mathrm{~h}$. Thus at least 121 of our nitrate-reducing strains formed DMN in $70 \mathrm{~h}$. Only two test cultures, one of $P$. rettgeri and one of $P$. morganii, gave yields that were lower than the $0.22 \mathrm{~mm}$ found in controls at $p \mathrm{H} 7.4$ and these were most probably not producing DMN enzymically.

\section{Nitrite toxicity}

Of the 140 cultures tested, 106 were dead after $70 \mathrm{~h}$ (table III) in medium enriched with DMA and $\mathrm{KNO}_{3}$. The substrate associated with the development of lethal conditions appeared to be $\mathrm{KNO}_{3}$, because all 140 cultures were viable in medium enriched with DMA alone, whereas, in medium enriched with $\mathrm{KNO}_{3}$ alone, 118 of the 140 cultures were dead, 101 of them being the same as those that were killed in medium enriched with both DMA and $\mathrm{KNO}_{3}$. Nitrite produced from $\mathrm{KNO}_{3}$ appeared to be the bactericidal agent because all four strains that did not reduce nitrate to nitrite were viable in medium enriched with either DMA and $\mathrm{KNO}_{3}$, or $\mathrm{KNO}_{3}$ alone. To test for possible toxicity of nitrite, one strain of $E$. coli and two of $P$. mirabilis were separately seeded to give $10^{6}$ organisms per $\mathrm{ml}$ in defined medium supplemented with $\mathrm{NaNO}_{2}$ in concentrations from $0.01 \mathrm{M}$ to $0.5 \mathrm{M}$. The maximum concentration of nitrite that would permit growth was $0.05 \mathrm{M}$ and in higher concentrations no viable organisms could be recovered after $24 \mathrm{~h}$. Since the test medium contained $0 \cdot 1 \mathrm{M} \mathrm{KNO}_{3}$ and the strains that died reduced nitrate to nitrite, nitrite toxicity is the probable explanation for the death of cultures recorded in table III and observed in the time-course experiments (figs. 1 and 2) as a sudden decrease in viable counts after about $30 \mathrm{~h}$. There was no evidence that DMN was the bactericidal agent. One strain each of $K$. aerogenes and $P$. mirabilis, both of which were dead at $70 \mathrm{~h}$ in medium enriched with either DMA and $\mathrm{KNO}_{3}$, or $\mathrm{KNO}_{3}$ alone, were viable at $70 \mathrm{~h}$ when grown in defined medium enriched either with $0.9 \mathrm{mM}$ DMN or with $9 \mathrm{mM} \mathrm{DMN}$, the maximum concentration produced by any culture.

\section{$D M N$ production by nitratase-negative strains}

To determine whether nitratase-negative strains could produce DMN from DMA and nitrite, five strains of $P$. mirabilis, including the two nitratasenegative strains B2 and B15, and five of $P$. vulgaris, including the two nitratasenegative strains, $A 15$ and B14, were incubated in defined medium supplemented with $0.022 \mathrm{M}$ DMA and either $0.025 \mathrm{M} \mathrm{NaNO}_{2}$ or $0.025 \mathrm{M} \mathrm{KNO}_{3}$. The low concentration of $\mathrm{NaNO}_{2}$ was chosen to avoid toxicity, and concentrations of DMA and $\mathrm{KNO}_{3}$ were made to maintain supplements in the same ratio as in other experiments. No detectable DMN was formed after $24 \mathrm{~h}$ by any of 
the cultures in either medium; however, after $70 \mathrm{~h}$ in defined medium supplemented with $\mathrm{NaNO}_{2}$ and DMA, all four nitratase-negative strains and four of the six nitratase-positive strains had produced some detectable DMN (table IV). Only the nitratase-positive strains produced detectable DMN after $70 \mathrm{~h}$ in medium supplemented with $\mathrm{KNO}_{3}$ and DMA. There was no detectable DMN formed either in uninoculated medium at $p \mathrm{H} 6.5$ or $7 \cdot 4$, or in inoculated controls without DMA or without $\mathrm{KNO}_{3}$ or $\mathrm{NaNO}_{2}$. After $70 \mathrm{~h}$, all cultures in this series were viable. These results show that the nitratase and nitrosamineforming enzymes are separate, because the nitratase-negative strains when supplied with nitrite were as active as nitratase-positive strains in producing DMN.

\section{Effect of different substrate concentrations}

The percentage conversion of DMA to DMN by each of the six nitratasepositive strains (table IV) was similar in media containing 0.022M DMA and $0.025 \mathrm{M} \mathrm{KNO}_{3}$ to the percentage in media containing $0.09 \mathrm{M}$ DMA and $0.1 \mathrm{M}$ $\mathrm{KNO}_{3}$. The amount of DMN produced appears to represent an equilibrium with the concentration of DMA.

\section{Discussion}

It has been suggested that bacteria causing urinary-tract infections may produce nitrosamines from secondary amines and nitrates in urine and, in support of this, bacteria found in urinary-tract infections such as E. coli (Sander, 1968; Hawksworth and Hill, 1971 and 1974), P. vulgaris (Sander, 1968), $P$. mirabilis, $P$. rettgeri and $P$. morganii (Thacker and Brooks, 1974) have been shown to produce nitrosamines in vitro. However, nitrosamine formation

TABLE IV

Dimethylnitrosamine (DMN) production in 24-h and 70- $h$ cultures in defined medium supplemented with $0.022_{M}$ dimethylamine (DMA) and either $0.025_{M} \mathrm{NaNO}_{2}$ or $0.025_{\mathrm{M}} \mathrm{KNO}_{3}$

\begin{tabular}{|c|c|c|c|c|c|}
\hline \multirow{3}{*}{ Species } & \multirow{3}{*}{$\begin{array}{l}\text { Nitratase } \\
\text { production }\end{array}$} & \multicolumn{4}{|c|}{ Concentration of DMN produced (mM) in } \\
\hline & & \multicolumn{2}{|c|}{$\mathrm{NaNO}_{2}$-supplemented medium } & \multicolumn{2}{|c|}{$\mathrm{KNO}_{3}$-supplemented medium } \\
\hline & & in $24 \mathrm{~h}$ & in $70 \mathrm{~h}$ & in $24 \mathrm{~h}$ & in $70 \mathrm{~h}$ \\
\hline P. mirabilis & $\begin{array}{l}- \\
- \\
+ \\
+ \\
+\end{array}$ & $\begin{array}{l}<0.0045 \\
<0.0045 \\
<0.0045 \\
<0.0045 \\
<0.0045\end{array}$ & $\begin{array}{c}0.114 \\
0.096 \\
0.058 \\
0.057 \\
<0.0045\end{array}$ & $\begin{array}{l}<0.0045 \\
<0.0045 \\
<0.0045 \\
<0.0045 \\
<0.0045\end{array}$ & $\begin{array}{c}<0.0045 \\
<0.0045 \\
0.419 \\
0.279 \\
0.254\end{array}$ \\
\hline P. vulgaris & $\begin{array}{l}- \\
- \\
+ \\
+ \\
+\end{array}$ & $\begin{array}{l}<0.0045 \\
<0.0045 \\
<0.0045 \\
<0.0045 \\
<0.0045\end{array}$ & $\begin{array}{c}0.096 \\
0.100 \\
0.019 \\
0.145 \\
<0.0045\end{array}$ & $\begin{array}{l}<0.0045 \\
<0.0045 \\
<0.0045 \\
<0.0045 \\
<0.0045\end{array}$ & $\begin{array}{c}<0.0045 \\
<0.0045 \\
0.490 \\
0.481 \\
0.486\end{array}$ \\
\hline
\end{tabular}


appeared to be an irregularly distributed property among strains of each species. Hawksworth and Hill (1971) found that only $27 \%$ of 37 strains of E. coli and even lower proportions of other intestinal bacteria formed diphenylnitrosamine; and, although Sander (1968) found that $P$. vulgaris formed diphenylnitrosamine, three strains of $P$. vulgaris failed to form DMN from urine under conditions in which other Proteus species produced it (Thacker and Brooks, 1974). Our own experience with 153 strains of E. coli, Klebsiella and Proteus spp. was similar; only 108 produced detectable DMN in $24 \mathrm{~h}$. However, ability to produce DMN appeared to be a constant property of particular strains, and the original object of the present investigation was to attempt to define those strains that produced DMN and were potentially capable of forming this carcinogen when they caused urinary-tract infections.

The results showed that differences in strains are probably of minor significance in comparison with host factors in the urinary tract. When cultures were incubated for $70 \mathrm{~h}$ instead of $24 \mathrm{~h}$ in defined medium enriched with DMA and $\mathrm{KNO}_{3}$, all nitratase-positive strains yielded $\mathrm{DMN}$; even after the most stringent allowance for non-biological formation, $89 \%$ of these appear to have done so enzymically. The major difference between strains was in the rate at which they formed DMN. Our tests after incubation for $24 \mathrm{~h}$, when DMN production was only starting, were misinterpreted by us as showing differences in capacity to form DMN. Hawksworth and Hill (1971) incubated their cultures for only $18 \mathrm{~h}$; this presumably explains why only $27 \%$ of their strains of $E$. coli appeared able to produce diphenylnitrosamine from nitrate and diphenylamine.

It appears that ability to produce DMN is widely distributed among enterobacteria. Biochemical attributes may be regarded as constant for a species if $80 \%$ of strains are positive (Cowan and Steel, 1965) and by this standard a nitrosamine-forming enzyme appears to be a constant property of $E$. coli, $K$. aerogenes, $P$. mirabilis and $P$. vulgaris, and possibly also of $K$. ozaenae, $P$. rettgeri and $P$. morganii, although there is variation among strains in the time of incubation at which the enzyme is first apparent. Some strains are already producing detectable DMN after $16 \mathrm{~h}$ and significant yields at $24 \mathrm{~h}$, but others are slower with very small yields at $24 \mathrm{~h}$, although the final yields of the slow producers may be larger than those of the faster ones.

The reverse reaction, breakdown of DMN to DMA by bacteria, has been reported (Hawksworth and Hill, 1971; Rowland and Grasso, 1975); the final yields of DMN probably represent an equilibrium between formation and degradation.

Conditions in the urinary tract analogous to prolonged incubation are likely to be important in determining the potential of an infection to produce carcinogenic nitrosamines. A wide variety of structural abnormalities and associated conditions such as ureteric reflux interfere with normal clearing mechanisms. Infected urine is retained in a semi-continuous culture system, and the infection may persist for many weeks or months. This is much more time than is necessary for even the slower DMN producers to yield the nitrosamine in our in-vitro test model. At the $p \mathrm{H}$ of urine, which can be as low as 
$4 \cdot 5$, non-biological DMN production might also occur-provided that an infecting organism first reduced nitrate to nitrite. On the other hand, in the absence of stasis, it is probable that urinary-tract infections do not pose a risk of DMN production, and procedures such as high fluid intake that tend to flush bacteria from the urinary tract would have the double value of reducing both the numbers of organisms and the time that they spend in the system. The finding that more than $12 \mathrm{~h}$ is needed for DMN production under favourably poised conditions in vitro and that production is not at a maximum for $70 \mathrm{~h}$ puts the importance of DMN produced in vivo in association with urinary tract infections into perspective and makes it clear that, unlike the general threat of all urinary-tract infections envisaged by Hill et al. (1973) and Thacker and Brooks (1974), infection without structural or functional abnormality would almost certainly not be a potent or persisting source of DMN.

Yields of nitrosamines reported in the literature are small. This is particularly true of the conversion of DMA to DMN, which can be calculated as $0.01 \%$ by $E$. coli in $18 \mathrm{~h}$ (Hill and Hawksworth, 1972), $0.09 \%$ by sewage bacteria in 8 days (Ayanaba, Verstraete and Alexander, 1973), and up to $0.05 \%$ by a cell suspension of $E$. coli in $36 \mathrm{~h}$ (Ayanaba and Alexander, 1973). Yields of DMN ranged from $0.001 \mathrm{~mm}$ to $0.03 \mathrm{~mm}$. Higher yields have been reported from the other secondary amines found in urine, piperidine and pyrrolidine (Hawksworth and Hill, 1974), but these amines are found in only a fraction of the concentration at which DMA occurs in urine (Hawksworth and Hill, 1972). We also found only small amounts of DMN produced in vitro after incubation for $24 \mathrm{~h}$; only 64 out of 153 strains converted more than $0.1 \%$ of $0.09 \mathrm{M}$ DMA to DMN and the maximum yield was only $0.36 \mathrm{~mm}$. However, with longer incubation the yield of DMN increased, and after $70 \mathrm{~h}$ up to $10 \%$ of the DMA in the medium was converted to DMN.

The concentrations of DMA and $\mathrm{KNO}_{3}$ used in the present investigation were high in comparison with those that might be expected in vivo. The normal concentration of DMA in human urine is $0.5 \mathrm{~mm}$ (Hawksworth and Hill, 1971) and we used $90 \mathrm{~mm}$. Urinary nitrate concentration depends on dietary intake and has been found to range from $1 \mathrm{~mm}$ to $2.6 \mathrm{~mm}$ (Hawksworth and Hill, 1971) whereas we used $100 \mathrm{~mm}$. Although the experiments were artificial to the extent that concentrations of reagents were under the constraint of the sensitivity of the gas chromatograph used to detect DMN, the six nitratase-positive strains used in the experiment with one-quarter the reagent concentrations, $22 \mathrm{mM}$ DMA and 25mM $\mathrm{KNO}_{3}$, converted similar proportions of the DMA to DMN. Studies that might relate our findings with these test systems more closely to natural circumstances are now indicated.

\section{SUMMARY}

Tests with 140 strains representing Escherichia coli, Klebsiella aerogenes, $K$. ozaenae, Proteus mirabilis, $P$. vulgaris, $P$. rettgeri and $P$. morganii in a defined medium supplemented with $0.09 \mathrm{M}$ dimethylamine (DMA) and 0.1M potassium nitrate showed that at least $89 \%$ of the 136 strains able to reduce nitrates 
produced up to $9 \mathrm{~mm}$ dimethylnitrosamine (DMN) in $70 \mathrm{~h}$ at $37^{\circ} \mathrm{C}$. Four nitratase-negative strains produced DMN from DMA in the presence of sodium nitrate. Prolonged incubation was the most important factor in determining DMN production. Stasis and persistent infection in the urinary tract, by simulating prolonged incubation of a culture, may be of importance in determining whether the potential carcinogen, DMN, could be produced in vivo by bacterial action on DMA and nitrate in urine.

We thank Miss Nance Quick for excellent technical assistance and Dr A. J. C. Nicholson, Division of Chemical Physics, Cornmonwealth Scientific and Industrial Research Organisation, for identifying dimethylnitrosamine by mass spectrometry. One of us (N. J. H.) was assisted by a grant from the National Health and Medical Research Council.

\section{REFERENCES}

Ayanaba, A. and Alexander, M. 1973. Microbial formation of nitrosamines in vitro. Appl. Microbiol., 25, 862.

Ayanaba, A., Verstraete, W. and Alexander, M. 1973. Possible microbial contribution to nitrosamine formation in sewage and soil. J. natl Cancer Inst., 50, 811.

Brooks, J. B., Cherry, W. B., ThaCker, L. ANd Alley, C. C. 1972. Analysis by gas chromatography of amines and nitrosamines produced in vivo and in vitro by Proteus mirabilis. J. infect. Dis., 126, 143.

Collins-Thompson, D. L., Sen, N. P., Aris, B., And Schwinghamer, L. 1972. Nonenzymic in vitro formation of nitrosamines by bacteria isolated from meat products. Can. J. Microbiol., 18, 1968.

Cowan, S. T. AND SteEL, K. J. 1965. Manual for the identification of medical bacteria, London.

FONG, Y. Y. AND CHAN, W. C. 1973. Bacterial production of dimethylnitrosamine in salted fish. Nature, Lond., 243, 421.

Hawksworth, G. M. AND HiLl, M. J. 1971. Bacteria and the N-nitrosation of secondary amines. Br. J. Cancer, 25, 520.

Hawksworth, G. ANd Hill, M. J. 1974. The in-vivo formation of N-nitrosamines in the rat bladder and their subsequent absorption. Br. J. Cancer, 29, 353.

Hill, M. J. ANd Hawksworth, G. 1972. Bacterial production of nitrosamines in vitro and in vivo. In $\mathrm{N}$-nitroso compounds: analysis and formation, edited by $\mathrm{P}$. Bogovski, R. Preussmann and E. A. Walker, IARC Sci. Publ. no. 3, Lyon, p. 116.

Hill, M. J., Hawksworth, G. AND TATTERSALl, G. 1973. Bacteria, nitrosamines and cancer of the stomach. Br. J. Cancer, 28, 562.

INTERNATIONAL AGENCY FOR RESEARCH ON CANCER. 1972. Report of the subcommittee on analytical methods for $\mathrm{N}$-nitroso compounds. In $\mathrm{N}$-nitroso compounds: analysis and formation, edited by P. Bogovski, R. Preussmann and E. A. Walker, IARC Sci. Publ. no. 3, Lyon, p. 92.

LIJINSKy, W. 1974. Reaction of drugs with nitrous acid as a source of carcinogenic nitrosamines. Cancer Res., 34, 255.

LIJINSKY, W. AND EPSTEIN, S. S. 1970. Nitrosamines as environmental carcinogens. Nature, Lond., 225, 21.

Magee, P. N. 1969. In vivo reactions of nitroso compounds. Ann. N.Y. Acad. Sci., 163, 717.

Miles, A. A., Misra, S. S. AND Irwin, J. O. 1938. The estimation of the bactericidal power of the blood. J. Hyg., Camb., 38, 732.

MiRvish, S. S. 1970 . Kinetics of dimethylamine nitrosation in relation to nitrosamine carcinogenesis. J. natl Cancer Inst., 44, 633.

Proom, H. and Knight, B. C. J. G. 1955. The minimal nutritional requirements of some species in the genus Bacillus. J. gen. Microbiol., 13, 474. 
Rowland, I. R. AND Grasso, P. 1975. Degradation of N-nitrosamines by intestinal bacteria. Appl. Microbiol., 29, 7.

SANDER, J. 1968. Nitrosaminsynthese durch Bakterien. Hoppe-Seyler's Z. physiol. Chem., $349,429$.

SANDER, J., Schweinsberg, F. AND Menz, H. P. 1968. Untersuchungen über die Entstehung cancerogener Nitrosamine im Magen. Hoppe-Seyler's Z. physiol. Chem., 349, 1691.

SEN, N. P., SmIth, D. C. AND Schwinghamer, L. 1969. Formation of N-nitrosamines from secondary amines and nitrite in human and animal gastric juice. Fd Cosmet. Toxicol., $7,301$.

THACKER, L. AND BRoOKs, J. B. 1974. In vitro production of $\mathrm{N}$-nitroso-dimethylamine and other amines by Proteus species. Infect. Immun., 9, 648. 